\title{
New species of neotropical Ipini Bedel, 1888 (Coleoptera: Curculionidae: Scolytinae)
}

\section{Новые виды неотропических Ipini Bedel, 1888 (Coleoptera: Curculionidae: Scolytinae)}

\author{
A.V. Petrov', T.H. Atkinson ${ }^{2}$ \\ А.В. Петров ${ }^{1}$, Т.Г. Аткинсон ${ }^{2}$
}

\footnotetext{
Institute of Forest Science of Russian Academy of Science, Sovetskaya st., 21, Uspenskoe, Moscow Region 143030, Russia. E-mail: hylesinus@list.ru

1 Федеральное государственное бюджетное учреждение науки Институт лесоведения Российской академии наук, ул. Советская, 21, Успенское, Московская область 143030, Россия.

${ }^{2}$ University of Texas Insect Collection, 3001 Lake Austin Boulevard, Suite 1.314 Austin, Texas 78703, USA. E-mail: thatkinson.austin@gmail.com
}

KEY WORDS: Coleoptera, Curculionidae, Scolytinae, Ipini, Acanthotomicus, Premnobius, Central and South America, new species.

КЛЮЧЕВЫЕ СЛОВА: Coleoptera, Curculionidae, Scolytinae, Ipini, Acanthotomicus, Premnobius, Центральная и Южная Америка, новые виды.

ABSTRACT. New species of Acanthotomicus Blandford, 1894 and Premnobius Eichhoff, 1879 are described from Central and South America: Acanthotomicus cognatoi and Premnobius perezdelacrucei spp.n.

How to cite this article: Petrov A.V., Atkinson T.H. 2018. New species of neotropical Ipini Bedel, 1888 (Coleoptera: Curculionidae: Scolytinae) // Russian Entomol. J. Vol.27. No.1. P.41-45. doi: 10.15298/ rusentj.27.1.06

РЕЗЮМЕ. Описаны новые виды короедов родов Acanthotomicus Blandford, 1894 и Premnobius Eichhoff, 1879 из Центральной и Южной Америки: Acanthotomicus cognatoi и Premnobius perezdelacrucei spp.n.

\section{Introduction}

In Central and South America the tribe Ipini is includes endemic species of Acanthotomicus Blandford, 1894, Ips De Geer, 1775, Orthotomicus Ferrari, 1867, and Pityogenes Bedel, 1888. The status of the genus Premnobius Eichhoff, 1879 has been problematical and controversial. For the most part this genus has been placed in the Xyleborini [sensu Alonso-Zarazaga, Lyal, 2009] by most authors. Wood acknowledged problems with this placement while retaining it in the Xyleborini. He indicated that the genus was "somewhat intermediate between Ipini and Xyleborus" [Wood, 1982] or "intermediate between Dryocoetini and Xyleborini" [Wood, 2007]. Browne [1961] reviewed known species and gave clear reasons based on morphology and behavior to argue against a relationship with the Xyleborini. More recent molecular studies have indicated a stronger relationship with the Ipini [Normark et al.,
1999; Farrel et al., 2001; Jordal et al, 2011; Jordal, Cognato, 2012; Cognato, 2013].

Most recently Cognato [2013] placed the Premnobiina as a subtribe of Ipini, also reviving Browne's [1961] genus Premnophilus Browne, 1961. As of this treatment the genus Premnobius consisted of 23 species endemic to sub-Saharan Africa, two of which are considered adventive to the Neotropics [Wood, 1982, 2007; Wood, Bright, 1992; Alonso-Zarazaga, Lyal, 2009; Cognato, 2013].

\section{Materials and Methods}

All specimens cited are deposited in the collections listed below.

CEAM - Centro de Entomología y Acarología, Colegio de Postgraduados, Montecillo, Mexico, Mexico;

CNIN - Colección Nacional de Insectos, Instituto de Biología, Universdid Nacional Autónoma de México, D.F., México;

UJAT - Universidad Juárez Autónoma de Tabasco, Villahermosa, Tabsco, Mexico;

UTIC - University of Texas University Collection, Austin, Texas, U.S.A.;

ZMM - Zoological Museum, Moscow State University, Russia.

Photographs were taken with a MP-E $65 \mathrm{~mm}$ macro lens and a Cannon 50D (A.V. Petrov) or Canon Eos Rebel (T.H. Atkinson) camera.

\section{Results}

Neotropical species of the genus Premnobius differ from Acanthotomicus by the elongate cylindrical 
pronotum which is at least $2 / 3$ the length of the elytra with an elevated antero-lateral margin (Figs 5-8). All species in the genus express strong sexual dimorphism, with flightless males. The four species treated here have dense pubescence on the lateral margins of the declivity with the most prominent tubercles or projections on the lower part of the decliviat crest. The pronotum of species Acanthotomicus is shorter, without the raised antero-lateral margin (Figs 1-4). The declivity has numerous small tubercles on the lateral margins of excavated area; those of the declivity of the male are larger than those of the female. The largest tubercles are on the upper part of the declivital crest and abundant pubescence is lacking. Males have fully functional wings.

\section{Acanthotomicus Blandford, 1894 Acanthotomicus cognatoi Petrov, sp.n. Figs 1-4.}

TYPE MATERIAL: Holotype $O^{7}$ (ZMM): PERU: Junín: $15 \mathrm{~km}$ NW from Satipo, near Rio Venado village, $1300 \mathrm{~m}$ a.s.1., $74^{\circ} 46^{\prime} 07.0^{\prime \prime} \mathrm{W}$ $11^{\circ} 11^{\prime} 35.2^{\prime \prime S}$, 3.X.2015, window trap., leg. A.V. Petrov.

TYPE LOCALITY: Satipo, Junín Region, Peru.

DESCRIPTION. Male. $2.45 \mathrm{~mm}$ long, 2.88 times as long as wide. Body uniformly brown, weakly shining.

Frons convex above, with a longitudinal median line above middle of the frons towards the vertex; lower part of the frons transversely impressed without median line, epistoma with poorly raised short median elevation; surface shining, with finely shagreened and moderately abundant rounded tubercles, tubercles rather coarse on upper part of the frons; vestiture of long sparse setae; eyes long, oval, entire; antenna yellowish brown, antennal club as long as scape, oval, slightly longer than wide, sutures strongly procurved marked by short pale setae, suture 1 extending beyond middle of club.

Pronotum brown, shining, 1.1 times as long as wide; lateral margins of pronotum straight and parallel on basal half, anterior margin rounded, basal margin of pronotum rounded in lateral areas and straight in center; summit slightly anterior to middle, anterior slope closely asperate; posterior half smooth, reticulate with numerous punctures; vestiture of sparse long hair, more conspicuous on margins.

Scutellum dark brown, triangular, smooth, shining.

Elytra uniformly brown, weakly shining; 1.64 times as long as wide, 1.52 times as long as pronotum, lateral margins straight and parallel from the base to apical margin; striae not impressed, punctures coarse, moderately deep, strial punctures separated by distance equal to the diameter of a puncture; interstriae slightly more than twice as wide as striae, smooth, punctures equal to those of striae, similarly impressed. Declivity occupying posterior one-fourth of elytral length, broadly, moderately concave, steep; lateral and lower margins subacutely elevated; denticle 1 pointed, conical, on margin at interstriae 2; denticle 2 on interstiae 3 , equal in size to denticle 1. Surface of concave area shining, sutural interstriae not elevated, punctures in clear rows. Vestiture of shorter erect hair-like setae in strial and longer in interstrial rows of lower part of elytral disc, lateral margins of elytral with very long yellowish-brown setae; vestiture on declivity shorter.

Metasternum and metepisternum reddish brown with short yellowish-brown setae. Abdomen reddish brown, ventrites with erect, short yellowish-brown setae. Legs reddish-brown, unicolored, covered by short yellowish-brown hairs.

Female unknown.
DIAGNOSIS: This new species is closely related to A. fortis (Wood, 1971) and would key to couplet 7 in Wood's [2007] key along with fortis. It can be distinguished by elytral vestiture and slender body, lateral margin on lower half of declivity without elevated, subacute, continuous, slightly undulating ridge; sutural interstriae not elevated.

ETYMOLOGY: This new species is named in honor of the entomologist Dr. Anthony I. Cognato (Michigan State University, USA), our friend and colleague, expert systematist in the Scolytinae and noted authority on the Ipini and Xyleborini.

\section{Premnobius Eichhoff, 1879 \\ Premnobius perezdelacrucei Petrov et Atkinson, sp.n.} Figs 5-8.

TYPE MATERIAL: Holotype + (ZMM): PERU: Junín: $15 \mathrm{~km}$ NW of Rio Venado vill., $1100 \mathrm{~m}$ a.s.1., 7446'07.0' 'W 11 '11'35.2' 'S, 3.X.2014, window trap., leg. A.V. Petrov. Paratypes: same locality, but 3.IV.2013, window trap., leg. A.V. Petrov (1 9 ); ECUADOR: Orellana, Yasuni N.P., Yasuni Res. Station, $76^{\circ} 23.9^{\prime} \mathrm{W} 0^{\circ} 40.4^{\prime} \mathrm{S}$, Canopy, 25 m, Sante, lower jar. 17-20.V.2008, leg. A.K. Tishechkin (1 + ); BRAZIL: São Paulo, Jardinópolis, 4744'10.44"W, $21^{\circ} 0^{\prime} 13.2^{\prime}$ S, 27.VII.2015, flight intercept trap baited with ethanol, N.A. Lima (MEFEIS, 1 ex.); Amapá, Tartarugalzinho, Retiro Paraíbo, $51^{\circ} 18^{\prime} 2.4^{\prime \prime} \mathrm{W}, 1^{\circ} 7^{\prime} 59.6^{\prime \prime} \mathrm{N}, 27 . X I .2014$, flightintercept trap baited with ethanol, W.R. Silva (MEFEIS, 1 ex.); MEXICO: Tabasco: Teapa, 30.III.2007, ethanol trap, M. Pérez de la Cruz (CNIN, 1 ex.); Huimangillo, km. 29 Carr. Huimanguillo-Francisco Rueda, 29.III.2013, ethanol trap, M. Pérez de la Cruz (CEAM, 1 ex.; UJAT, 1 ex.); PANAMA: Prov. Panamá (Canal Zone), Albrook Forest, Fort Clayton, 7.III.1968, R. Hutton (UTIC, 1 ex.).

TYPE LOCALITY: Satipo, Junín Region, Peru; Ecuador; Mexico; Panama.

DESCRIPTION. Female. $2.45 \mathrm{~mm}$ long, 4.0 times as long as wide (Figs 5-8). Body reddish-brown, shining. Head reddish-brown smooth, shining, frons convex, surface in lower part glabrous, punctured by sparse small rounded punctures, lateral and upper parts of the frons weakly finely shagreened, vestiture sparse on central part, more abundant, long setae in lateral part and epistomal process. Eyes weakly emarginate, large, coarsely faceted. Antennae reddish brown, scape as long as club, club round, strongly flattened, with light short setae, sutures strongly procurved.

Pronotum reddish-brown weakly shining, elongate, 1.66 times as long as wide, length nearly 3/4 length of elytra, rounded in base and anterior margin; base of pronotum nearly straight, 3/4 length of pronotum with acutely elevated margins, curving arcuately downwards anteriorly, pronotum widest in middle; anterior margin weakly irregularly serrate; anterior slope asperate, covered by small flat asperities in anterior part, summit and basal areas unicolored; surface of $3 / 4$ pronotal disc from basal part to anterior slope glabrous, clearly punctured by sparse small rounded points; vestiture of sparse, short yellow setae in pronotal disk and more abundant, long setae in antero-lateral and lateral parts of pronotum. Scutellum very small, triangular, brown.

Elytra reddish brown, weakly shining, 2.41 times as long as wide, 1.41 times as long as pronotum. Sides subparallel and tapering toward apex on posterior 3/4 of length; disc occupying basal 65 percent; surface glabrous, shining, punctured by rows of small, confused round points. Declivity broadly, deeply excavated; base concave with a miniscule tubercle on interstriae 2, a latger pointed tubercle on the upper part of the declivity, displaced mediad from declivital crest; the crest of posterior third of lateral margin 


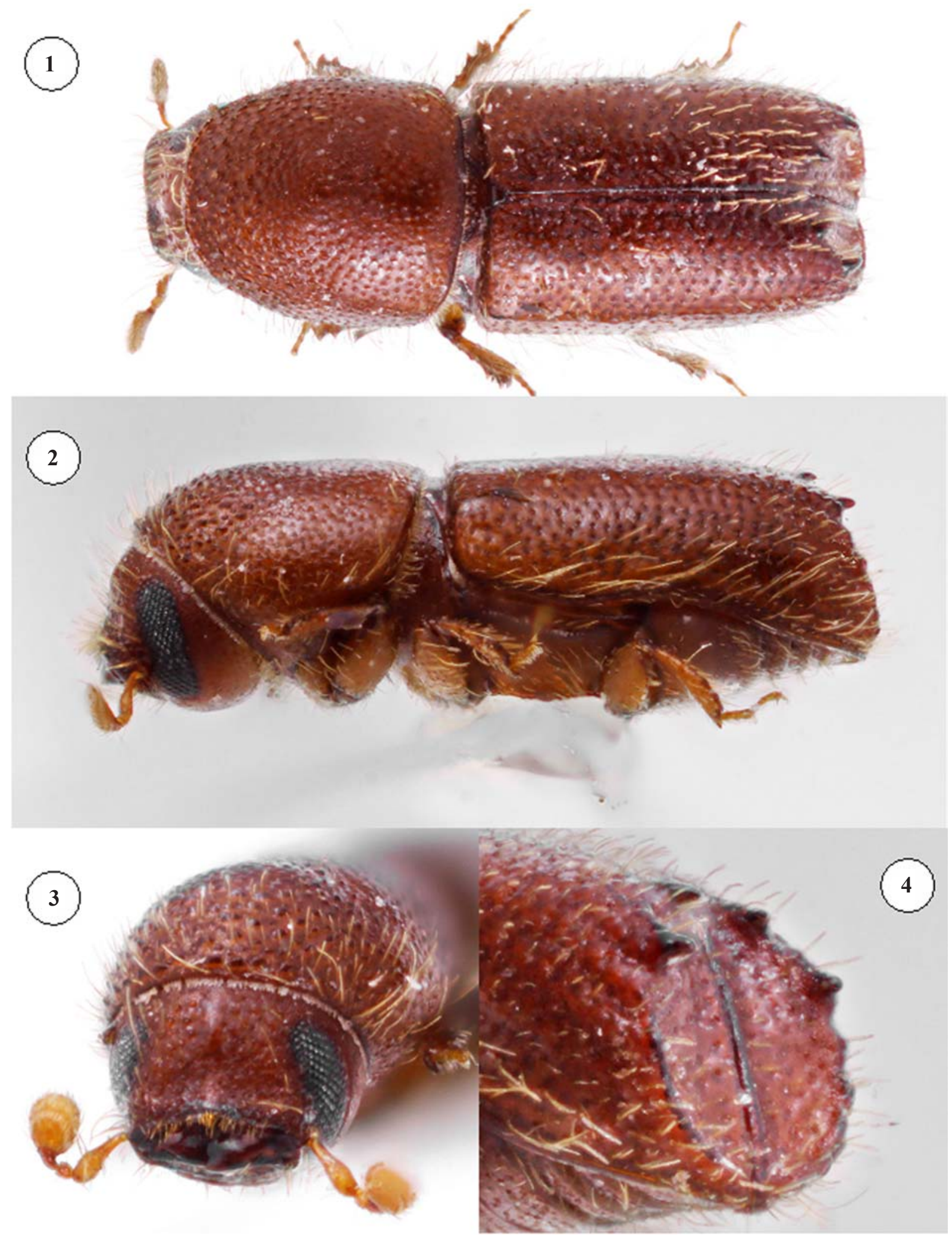

Figs 1-4. Acanthotomicus cognatoi sp.n., male, holotype: 1 - dorsal view; 2 - lateral view; 3 - frontal view; 4 - declivity. Photos by A.V. Petrov.

Рис. 1-4. Acanthotomicus cognatoi sp.n., самец, голотип: 1 - сверху; 2 - сбоку; 3 - спереди; 4 - вдавление надкрылий, самец. Фотографии А.В. Петрова. 


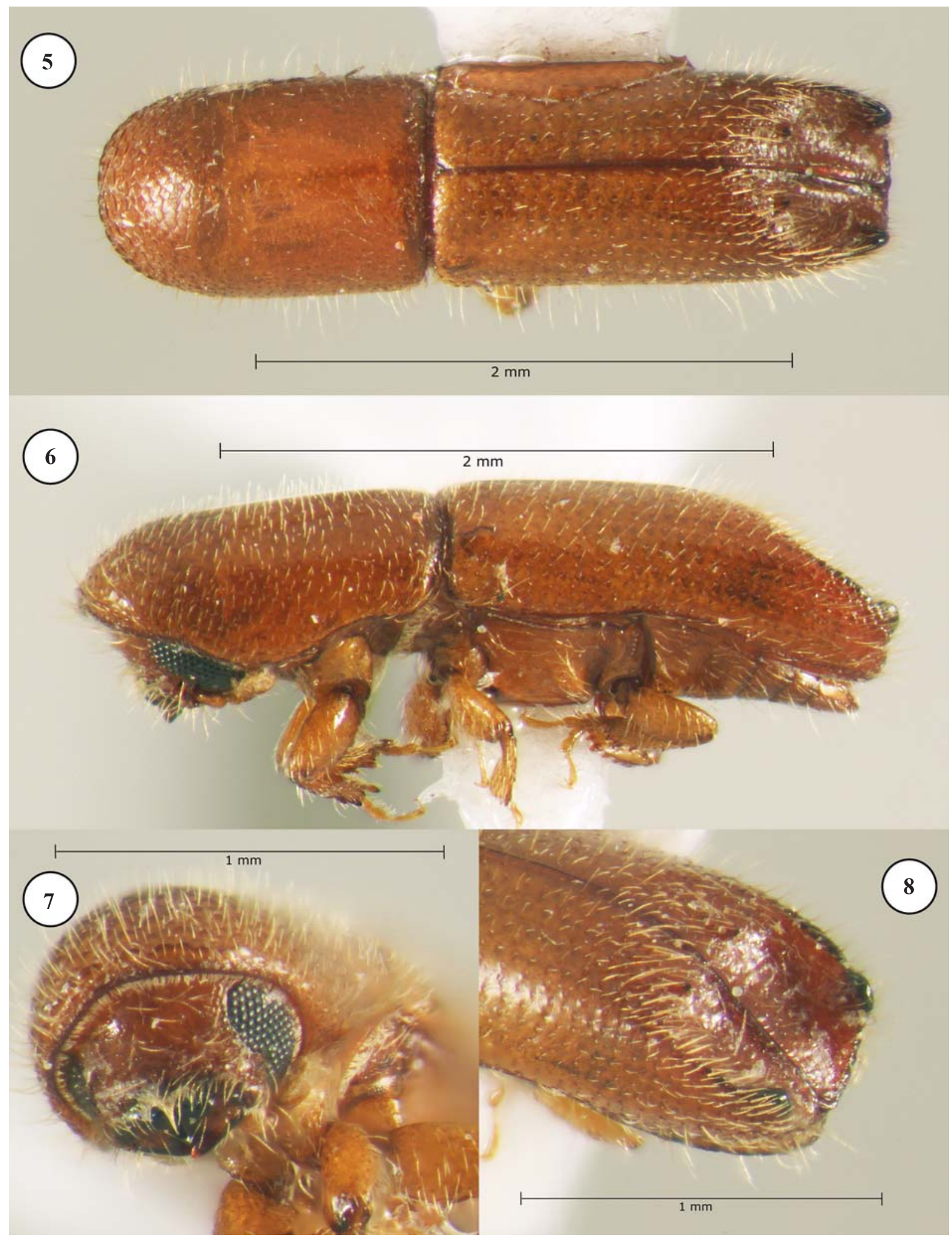

Figs 5-8. Premnobius perezdelacrucei sp.n., female, paratype: 5 - dorsal view; 6-lateral view; 7 - frontal view; 8 - declivity. Photos by T.H. Atkinson.

Рис. 5-8. Premnobius perezdelacrucei sp.n., самка, паратип: 5 - сверху; 6 - сбоку; 7 - спереди; 8 - вдавление надкрылий. Фотографии Т.Х. Аткинсона. 
declivity strongly elevated into large subquadrate process; surface of concave area shining, punctures confused, small. Vestiture of the elytral disk with sparse, fine and short erect hair, surface of the base of declivity with rows of abundant longer hair on interstriae, shorter and sparser on the posterior part of declivity.

Metasternum and metepisternum reddish brown with short yellowish-brown setae. Abdomen reddish brown, ventrites with erect short yellowish-brown setae. Legs reddish-brown, unicolored, covered by short yellowishbrown hairs.

Male unknown.

DIAGNOSIS: The new species is closely related to Premnobius cavipennis Eichhoff, 1878, but can be distinguished by tubercles on the base of declivity and declivital crest.

DISTRIBUTION: Known from subtropical forest of Central and South America (Mexico, Panama, Ecuador, Peru and Brazil).

ETYMOLOGY: This new species is named in honor of the entomologist Manuel Pérez de la Cruz (División Académica de Ciencias Biológicas, Universidad Autonoma Juárez de Tabasco, Villahermosa, Tabasco, Mexico).

ACKNOWLEDGEMENTS. The author expresses his most sincere gratitude to Dr. Harald Schillhammer and Dr. Helen Shaverdo (Naturhistorisches Museum Wien, Austria) for providing access to the collection of Karl E. Schedl. Dr. Kirill Makarov (Moscow) is thanked for providing photographs of the microscopic slides. We specially thank Dr. Alexey K. Tishechkin for providing material from Ecuador.

A.V. Petrov's research was supported by a grant from the Russian Fund for Basic Research (No.17-04-00360).

\section{References}

Alonso-Zarazaga M., Lyal C.H.C. 2009. A catalogue of family and genus group names in scolytinae and platypodinae with nomenclatural remarks (Coleoptera: Curculionidae) // Zootaxa. Vol.2258. P.1-134.

Browne F.G. 1961. The generic characters, habits and taxonomic states of Premnobius Eichh. (Coleopt., Scolytidae) // Annual Report Este African Timber Research Unit. Vol.4. P.45-51.

Cognato A.I. 2013. Molecular phylogeny and taxonomic review of Premnobiini Browne, 1962 (Coleoptera: Curculionidae: Scolytinae) // Frontiers in Ecology and Evolution. Phylogenetics, Phylogenomics, and Systematics. Vol.1. P.1-11.

Farrell B.D., Sequiera A.S., O’Meara B.C., Normark B.C., Chung J.H., Jordal B.H. 2001. The evolution of agriculuture in beetles (Curculionidae: Scolytinae and Platypodinae) // Evolution. Vol.55. No.10. P.2011-2027.

Jordal B.H., Sequeira A.S., Cognato A.I. 2011. The age and phylogeny of wood boring weevils and the origin of subsociality // Mol. Phylogenet. Evol. Vol.59. P.708-724.

Jordal B.H., Cognato A.I. 2012. Molecular phylogeny of bark and ambrosia beetles reveals multiple origins of fungus farming during periods of global warming // BMC Evol. Biol. Vol.12. No.1. P.1-133.

Normark B.B., Jordal B.H., Farrell B.D. 1999. Origin of a haplodiploid beetle lineage // Proc. R. Entomol. Soc. London. Ser. B. Vol.266. No.1435. P.2253-2259.

Schedl K.E. 1967. Neotropische Scolytoidea, IX. 251 Beitrag // Opus. Zool. München. Bd.99. S.1-19.

Wood S.L. 1982. The bark and ambrosia beetles of North America (Coleoptera: Scolytidae). A taxonomic monograph // Great Basin Nat. Mem. Vol.6. P.1-1359.

Wood S.L. 2007: Bark and ambrosia beetles of South America (Coleoptera: Scolytidae). Monte L. Bean Science Museum, Brigham Young University, Provo, Utah. 900 p.

Wood S.L., Bright D.E. 1992. A catalog of Scolytidae and Platypodidae (Coleoptera), Part 2: taxonomic index // Great Basin Nat. Mem. Vol.13. P.1-1553. 